\title{
Urgences
}

\section{Jardin de pierre : octobre}

\section{Cécile Cloutier}

Numéro 16, mars 1987

D.G. Jones : d'un texte, d'autres

URI : https://id.erudit.org/iderudit/025376ar

DOI : https://doi.org/10.7202/025376ar

Aller au sommaire du numéro

Éditeur(s)

Urgences

ISSN

0226-9554 (imprimé)

1927-3924 (numérique)

Découvrir la revue

Citer ce document

Cloutier, C. (1987). Jardin de pierre : octobre. Urgences, (16), 26-27.

https://doi.org/10.7202/025376ar

Ce document est protégé par la loi sur le droit d'auteur. L'utilisation des services d'Érudit (y compris la reproduction) est assujettie à sa politique d'utilisation que vous pouvez consulter en ligne.

https://apropos.erudit.org/fr/usagers/politique-dutilisation/
Cet article est diffusé et préservé par Érudit.

Érudit est un consortium interuniversitaire sans but lucratif composé de l'Université de Montréal, l'Université Laval et l'Université du Québec à Montréal. Il a pour mission la promotion et la valorisation de la recherche. https://www.erudit.org/fr/ 


\section{Cécile Cloutier JARDIN DE PIERRE: OCTOBRE}

Dans la pluie, il est une ruine

d'ombres, il est

la tombe des fleurs

Il recueille les couleurs

des feuilles tombées. Encore

il est les pierres qui fleurissent

comme un rassemblement de tomes

où ceux qui sont partis continuent

de parler

De plus en plus ma bouche

est pleine de pierres

et les os de mes collègues

ressemblent à des fleurs

Est-il la confusion, paradis

ou Angkor Wat

ou la cité secrète après

10 P.M.? Il n'est pas

vivant ou mort

ou humain. Je passe à travers

dans la pluie, dans les ténèbres. Il est

une croissance de runes 
Il m'a semblé que la traduction la plus littérale possible était pour moi la façon de vivre ce poème et de le rendre mien. Si j'en avais fait du Cloutier, cela serait devenu à la fois du mauvais Jones et du faux Cloutier. Ces thèmes ne sont pas les miens et ne m'enrichissent que dans la mesure où ils viennent d'un autre. La traduction demeure pour moi une fidélité. La sonoritê changeant d'une langue à l'autre, il faut au moins que le sens demeure, pur, intact, rond. J'ai longtemps étudié et enseigné le latin et le grec. Je m'y sentais protégée, rassurée par la rigueur de la version et du thème, comme dans une maison. Je ne suis pas bien devant des traductions qui ne traduisent pas. Je veux lire le poète, pas le traducteur. Quand je traduis, je me sens au service de... Cette langue n'est pas mienne. Je n'y retrouve pas mes mots avec mon histoire et mon devenir. Cette façon d'écrire de la poésie avec des trucs, des jeux, un trop de langage, ne correspond pas à mon univers intérieur, à ce que je sens comme la poésie. Mais je crois que la traduction est un respect de l'autre, de l'autrement. 